
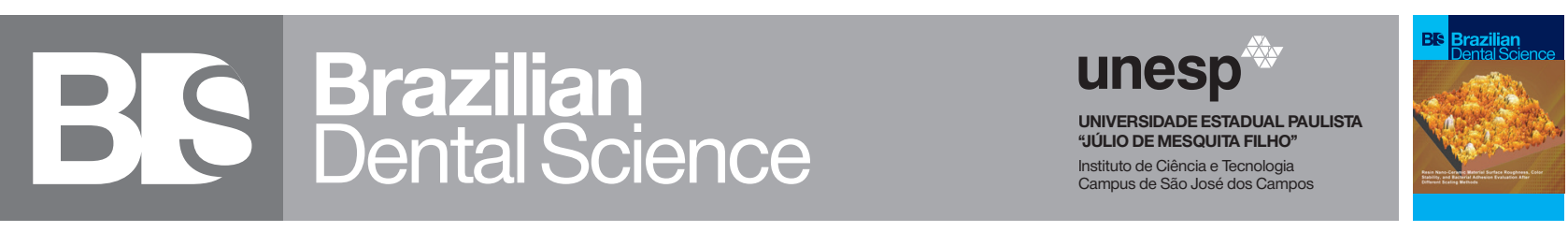

\title{
Reconstruction of extensive sequel of frontal fracture: optimizing results
}

\author{
Reconstrução de extensa sequela de fratura frontal: otimizando resultados \\ LOPES $^{4}$, Ozawa BRASIL JÚNIOR ${ }^{4}$, Ricardo José de Holanda VASCONCELLOS ${ }^{1}$ \\ 1 - Department of Oral and Maxillofacial Surgery. University of Pernambuco. Recife, Pernambuco, Brazil. \\ 2 - Maxillofacial Surgery and Traumatology Program at Hospital da Restauração. Recife, Pernambuco. Brazil. \\ 3 - University of Pernambuco. Recife, Pernambuco, Brazil \\ 4 - Department of Oral and Maxillofacial Surgery of UNIVASF. Petrolina, Pernambuco, Brazil.
}

Emerson Filipe de Carvalho NOGUEIRA ${ }^{1}$, Rosa Rayanne Lins de SOUZA ${ }^{2}$, Ladyanne Pavão de MENEZES ${ }^{3}$, Pedro Henrique de Souza

\section{ABSTRACT}

Introduction: Fractures of the frontal bone correspond to 5 to $15 \%$ of all facial fractures. This type of fracture can lead to difficulties in restoring bone congruence and to postoperative secondary aesthetic problems. Objective: This paper aims to present a clinical case report of frontal bone fracture where a late reconstruction was performed using a titanium mesh with the aid of stereolithographic model prototyping. Case report: Female patient, 26 years old, with aesthetic sequelae in the upper third of the face after a motorcycle accident. The imaging exams showed a comminuted frontal bone fracture, as well as upper edge and right orbit ceiling involvement. The planning consisted of reconstruction of the affected area with the use of a titanium mesh pre-shaped in a stereolithographic model. The procedure was performed under general anesthesia and coronal access. After installation of the fixation material, pericranial flap rotation and suture of the surgical wound were performed. The patient progressed well, with considerable improvement in facial aesthetics. Conclusion: This paper reports the importance of good planning in cases of frontal bone fracture sequel, in which the use of modelshaped mesh in a stereolithographic model tends to optimize surgery, bringing aesthetic and psychosocial benefits.

\section{KEYWORDS}

Frontal bone; Titanium; Craniocerebral trauma.

\section{RESUMO}

Introdução: As fraturas do osso frontal correspondem de 5 a $15 \%$ de todas as fraturas faciais. Esse tipo de fratura pode levar a dificuldades na restauração da congruência dos ossos e a problemas secundários estéticos pósoperatórios. Objetivo: Este trabalho objetiva apresentar um relato de caso clínico de fratura do osso frontal onde foi realizada reconstrução tardia utilizando tela de titânio com auxílio da prototipagem de modelo estereolitográfico. Relato de caso: Paciente do sexo feminino, 26 anos, apresentando sequela estética em terço superior da face após acidente motociclístico. Os exames de imagem demonstraram fratura cominutiva em osso frontal, além de envolvimento de bordo superior e teto de órbita direita. O planejamento consistiu de reconstrução da área afetada com uso de tela de titânio pré-modelada em modelo estereolitográfico. O procedimento foi realizado sob anestesia geral e acesso coronal. Após instalação do material de fixação optou-se pela rotação de retalho de pericrânio e sutura da ferida cirúrgica. A paciente evoluiu bem, com melhora considerável da estética facial. Conclusão: Este trabalho relata a importância do bom planejamento em casos de sequela de fratura do osso frontal, no qual o uso de telas modeladas em modelo estereolitográfico tendem otimizar a cirurgia, trazendo benefícios estéticos e psicossociais.

\section{PALAVRAS-CHAVE}

Osso frontal; Titânio; Traumatismo Craniocerebral. 


\section{INTRODUCTION}

7 ractures of the frontal bone correspond to 5 to $15 \%$ of all facial fractures [1]. This type of fracture can lead to difficulties in restoring bone displacements and postoperative secondary aesthetic problems. Due to their intimate contact with the structures of the anterior fossa of the skull, these affections are often associated with late repair treatments, since it becomes a priority to stabilize the patient's neurological condition before any reconstructive intervention, which can result in evident facial disharmony and difficult to treat [2].

In facial reconstructions, we can use different types of grafts or materials to be used as bone substitutes, they can be resorbable or not. For this, they must obey criteria whose effects on the human body are the least possible. A good example is the excellent biocompatibility of titanium and its easy handling that enable its use in the treatment of frontal bone fractures [3].

Rapid prototyping is a technology capable of physically reproducing a virtual model in various types of materials, represented in the form of data on a computer. The prototyping systems used in the construction of the bio models can be classified in: systems based on liquids, systems based on powder, systems based on solids. The rapid prototyping bio models are biomedical prototypes obtained from computed tomography (CT), magnetic resonance and ultrasonography, and can be used for didactic purposes in the manufacture of personalized prosthetic implants, early diagnosis and treatment of facial deformities. It also facilitates the communication between professional and patient [4].

The objective of this paper is to present a report of a clinical case of frontal bone fracture where late reconstruction with a titanium screen was used with the aid of prototyping with a stereolithographic model.

\section{CASE REPORT}

A 26-year-old female victim of a motorcycle accident was taken to the hospital emergency room where she was diagnosed with Traumatic brain injury (TBI) and a comminuted frontal bone fracture with encephalic matter exposure. A surgical procedure was performed by the neurosurgery team for partial frontal craniotomy, removal of the frontal sinus membrane, obliteration of the nasofrontal duct with pericranium and dura mater suture. After 5 days of recovery in Intensive Care Unit (ICU) and later in ward, she was discharged from hospital and underwent ambulatory follow-up. One year later, the patient complained of facial deformity and local touch discomfort. She was directed to the Maxillofacial Surgery outpatient clinic presenting no neuro motor or cognitive sequelae (except for slight right palpebral ptosis, with no alterations in ocular motility and / or visual acuity), but with a large depression in the frontal region (Figure 1).

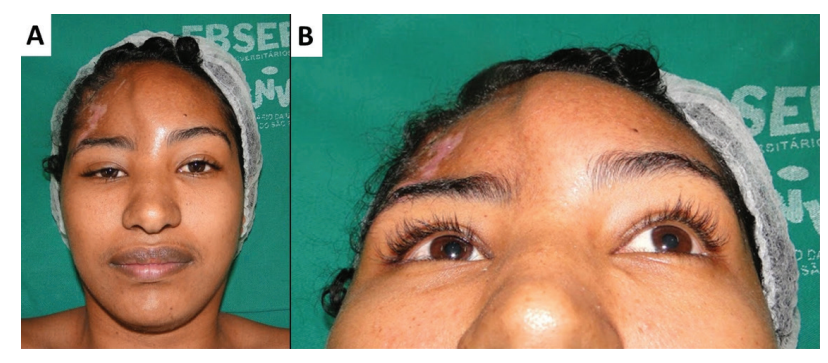

Figure 1 - Preoperative: A) Front view. B) Axial view.

A multi-slice computed tomography confirmed the absence of right part of the frontal bone including part of the orbital ceiling (Figure 2A). It was decided to rebuild it with titanium mesh. Prototyping with a stereolithographic model (Figure 2B) was performed by the Technology Information Center Renato Archer Campinas - SP, Brazil, for the surgical planning and adaptation of the titanium mesh $(0.5 \mathrm{~mm}$ thickness) to the bone defect. 


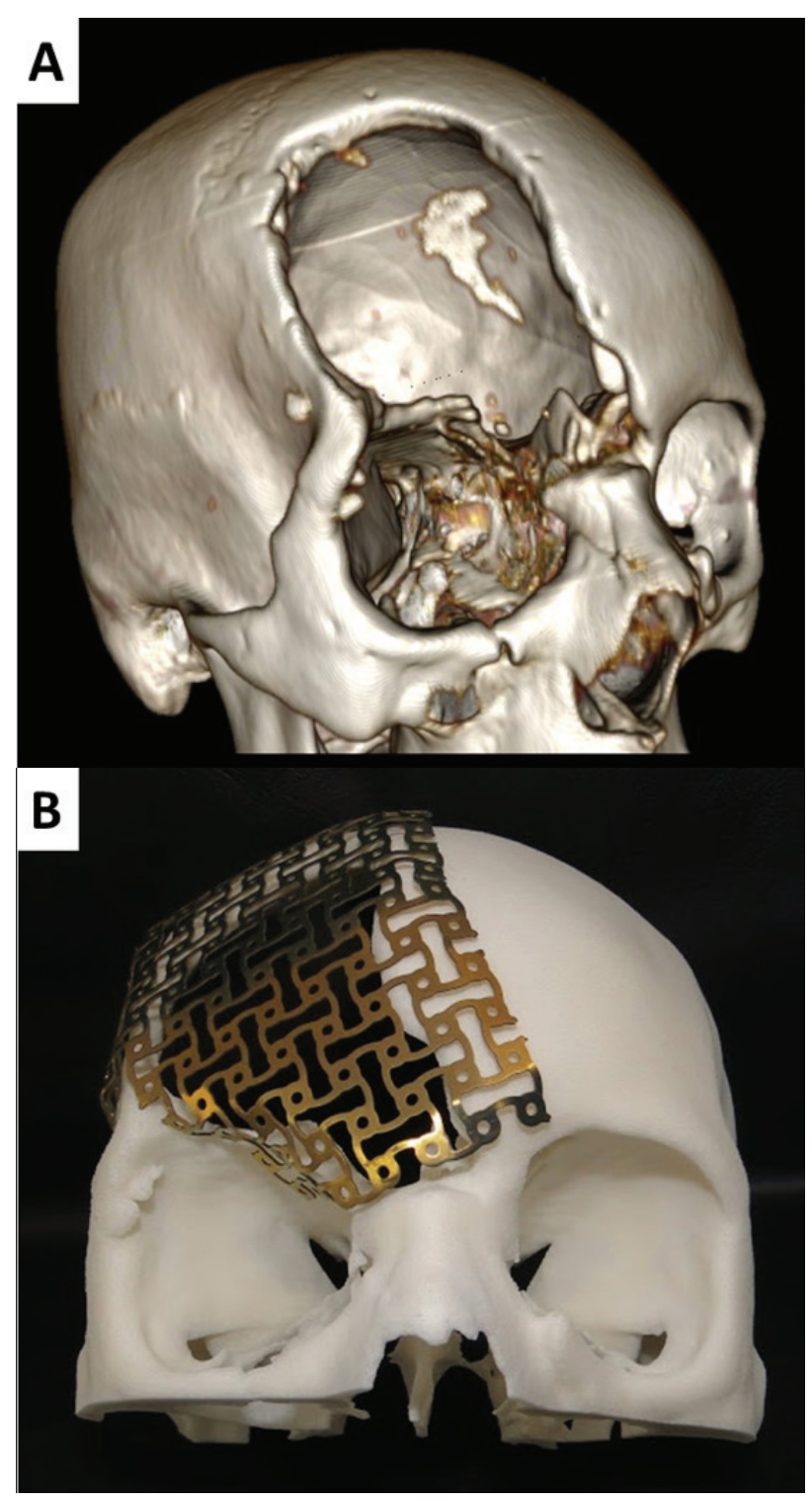

Figure 2 - A) Computed tomography in 3-D reconstruction demonstrating the defect in the upper third of the face. B) Predesigned titanium mesh in prototype.

After this stage, the patient underwent surgery, where coronal access and subperiosteal detachment were performed until the site of the bone defect, followed by delicate supraperiosteal dissection for preservation of the dura mater and orbital neuromuscular component performed in conjunction with the neurosurgery team (Figure 3A). After all surgical site exposure, copious irrigation with $0.9 \%$ saline solution and hemostasis, the predesigned titanium mesh was adapted to the site and fixed with titanium screws $2.0 \times 5 \mathrm{~mm}$, covering the entire frontal region and orbital ceiling (Figure 3B). A flap of pericranium was displaced and sutured to the titanium mesh to cover it (Figure 3C). A vacuum suction drain 3.2 was installed and the wound internally sutured with Vycril ${ }^{\circledR}$ 2-0 thread and externally with Nylon 2-0.

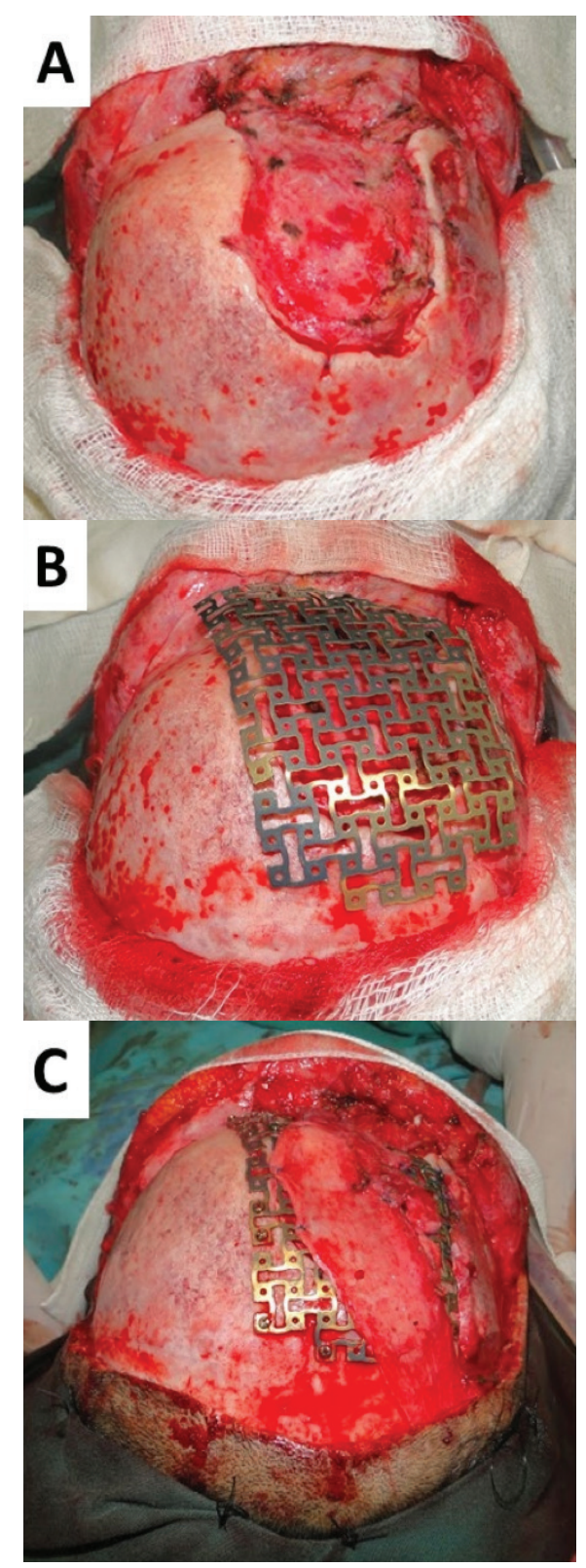

Figure 3 - A) Coronal access and exposure of the bone defect. B) Installation of the titanium mesh. C) Rotation of the pericranium flap. 
After 48 hours the drain was removed and the patient was discharged, evolving well, without signs of infection and / or dehiscence, without neuromotor changes in the face, without headache and with good frontal projection. The patient has been in outpatient follow-up for 1 year (Figures 4 and 5) with no functional and / or aesthetic complaints.
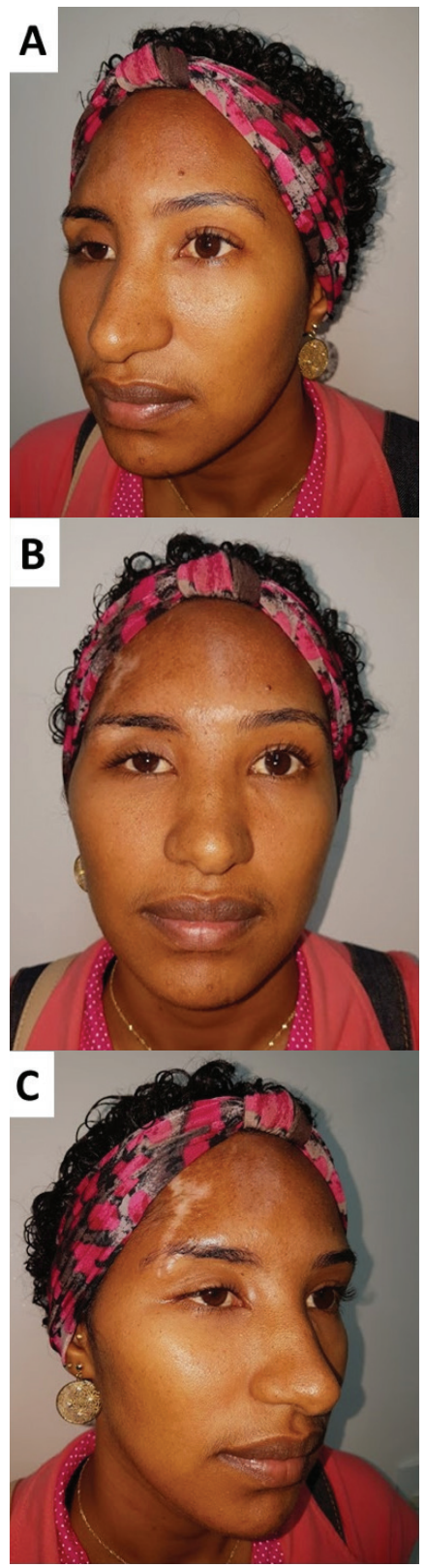

Figure 4 - Postoperative: A) Left lateral view. B) Front view. C) Right lateral view.
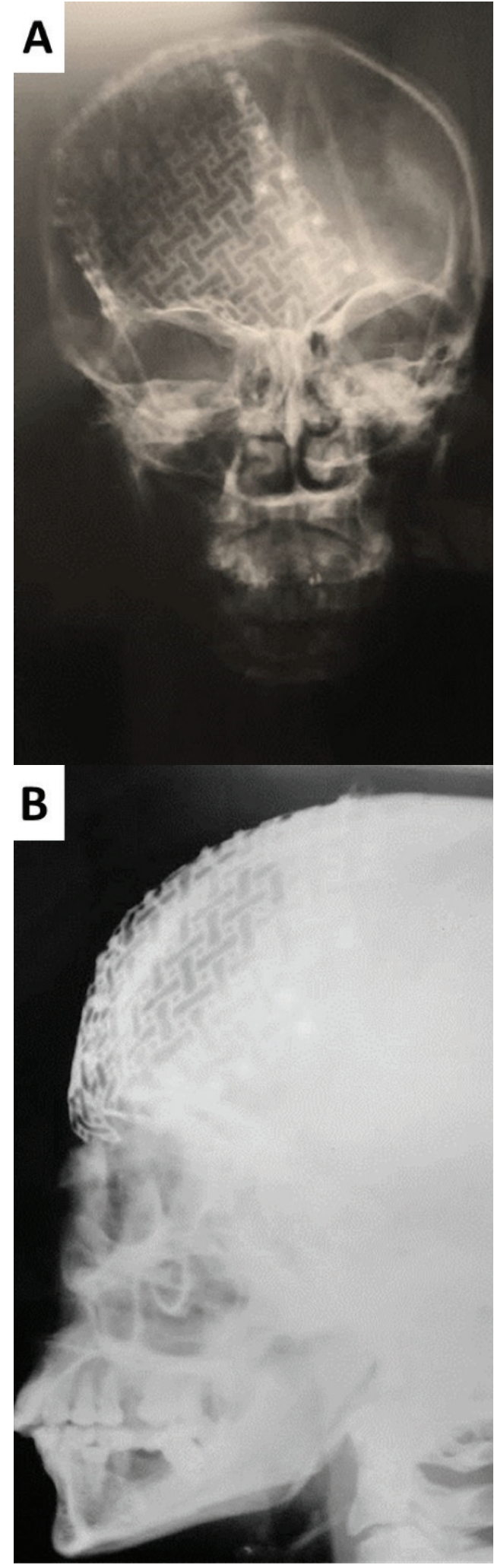

Figure 5 - Postoperative radiographs: A) Face PA. B) Face profile. 


\section{DISCUSSION}

Frontal bone fractures are usually associated with vehicle accidents and may be associated with alcohol and drug use, related to high speed of the vehicle where the intensity of the trauma involves high energy [5]. In the reported case, the patient suffered traumatic brain injury after a motorcycle accident with exposure of brain matter. The age group with the highest incidence of frontal fractures is from 21 to 30 years of age [5]. In the reported case, the patient was 26 years old, which was in agreement with the range in cases reported in the literature.

Due to its low incidence, when compared to other maxillofacial fractures, the treatment of frontal fractures is still a debatable issue. However, we can say that the timing of the intervention will depend, variably, on the type and extent of the fracture and the possible associated injuries [6]. Treatment goals are basically the prevention of infection, isolation and protection of intracranial content, correction of drainage of cerebrospinal fluid, restoration of function and aesthetics [7]. In the reported case, the intervention was performed after stabilizing the general health of the patient, which is preferable, since her complaint was mainly related to aesthetics.

The goal with patients with facial fractures is to reconstruct the structural integrity of the craniofacial skeleton and restore its morphology. The use of biomaterials for implants is an integral part of reconstructive and aesthetic facial surgery [8]. The prostheses used for cranial reconstruction may be of various alloplastic materials such as hydroxyapatite (HA), titanium and polymethylmethacrylate. Some materials can be molded or shaped during surgery and others manufactured in a customized way. These materials should have some characteristics to be considered suitable: biocompatibility, compatibility with imaging exams, ease of handling and shaping, adequate resistance (bone-like) and sterilizable [9]. In craniofacial surgeries, titanium is practically the only metal used [8]. Among the advantages of using the titanium plate and mesh system are immediate viability without damage to the site and patient, easy handling as they can be adapted and attached in few minutes and the possibility of recovering anatomical details that were present before the trauma. Some concerns related to the use of these metals are bone atrophy, palpability, device loosening, temperature sensitivity and interference with radiation therapy and imaging diagnosis [8]. However, the success of the procedures is associated with the quality of the biomaterial and rapid prototyping, which proves to be an important tool, aiding in the treatment of these lesions, since it facilitates reconstruction and reduces the morbidity associated with these defects [4]. Through modern rapid prototyping (RP) technologies, one can construct prototypes from a computer-generated model in a CAD (Computer Aided Design) CAM (Computer Assisted Manufacturing) program. The bio models of RP are biomedical prototypes obtained from computed tomography (CT), magnetic resonance imaging and ultrasonography images, and can be used for didactic purposes in the manufacture of personalized prosthetic implants, early diagnosis and treatment of facial deformities, which supports the communication between professional and patient [10]. The first prototyping system developed was stereolithography, due to the pioneering of this technique, the term stereolithography is still widely used today as synonymous with rapid prototyping. The stereolithography apparatus consists of a container containing photopolymerizable liquid resin. In this process, an ultraviolet laser beam selectively polymerizes the liquid layers of the photocurable resin with epoxy or acrylic, forming the model [4].

Several authors advocate the use of rapid prototyping technologies for implant making. In cases of sequelae of facial fractures or resections, bio models have a great contribution to the 
planning and intraoperative determination of osteotomy site, to decrease surgery duration, increase safety, decrease blood loss and determination of the contours of the prosthesis, thus considerably improving the final treatment result. This tends to reduce the duration of the surgical procedure and, consequently, the period of anesthesia, as well as the risk of infection, with an improvement in the result and a reduction in the overall cost of treatment [10]. In the case reported was associated with rapid prototyping by the technique of steriolithography to obtain a surgical prototype in order to assist in the planning of the procedure and corroborate in the reduction of the operative time and of possible morbidities linked to the intervention, such as the risk of infection. In order to avoid a greater dead space between the titanium mesh and the dura mater, the contour of the latter did not obey the rigor of the skull curvature [10].

Regarding the approach used for the fracture of the frontal bone, we can consider: coronal incision can be performed in the extensive fractures, in which the formation of non-aesthetic scars by the baldness can happen in the men and even accelerate the baldness process; on the other hand with the incision below the eyebrow (incision in "butterfly wing"), it is possible to diminish the extension of the scars, because they are small incisions, following the lines of force, but used in focal bone defects. However, it should be performed in a careful manner and with respect to the anatomy of the region, as there are reports of persistent hyperesthesia in the glabella region and frontal by lesions of the supraorbital nerves [11]. Considering the extent of the lesion and the implications associated with types of accesses, it was decided to carry out the reported case approach through coronal access, since there was an extensive bone loss.

The quality of the scalp cover directly influences the choice of surgical approach. Regardless of the material used, cranioplasty should have a well vascularized tissue covering.
Local flaps, tissue expansion, and free flaps are alternatives to good coverage. Skin grafts do not enter into the options for cranioplastic coverage [9], since skin dehiscence, whether small or large, is sovereign because it allows the inoculation of bacteria to the underlying bony flap and / or implant, which can lead to an irreversible infection and eventual removal [4].

In large defects or irradiated areas, we should think of free flaps or tissue expansion. In graft cranioplasty, the addition of a flap of pericranium over the reconstructed area should be performed whenever possible [9]; in this report, this technique was chosen to cover the titanium mesh favoring the contour and local protection.

The possible complications of cranioplasties are: laceration of the dura mater, subgaleal hematoma, infection of the surgical site, nonintegration of the prosthesis, graft or prosthesis extrusion, irregularities of the cranial contour and possible brain injury. Dura mater lacerations are avoided by checking the good definition of the patient's diploe in the preoperative period and using good surgical material. The appearance of cerebrospinal fluid fistulas and damage to the eyeball may be present correlated with the incidence of trauma. The approach in the most serious lesions, such as cerebrospinal fluid fistulas, orbital or optic nerve injuries, should be as a matter of urgency, and the intervention should be performed within a maximum of 3 days after the trauma to reduce the rate of late complications such as severe ocular lesions, permanent anosmia, meningitis, fistulae, cerebellar abscesses, and death [12]. However, if there is damage to the dura mater, it is considered a mild complication and should be corrected immediately as if it was with the peritoneum or pleura [9]. In this case, one year after the surgical treatment no complications were observed.

\section{CONCLUSION}


The cranioplasty performed in patients with fracture sequelae of the upper third of the face with the use of titanium mesh seeks primarily to repair the protective function of the skull, consequently restoring the cranial contour, bringing a great esthetic and psychosocial benefit. For this, it is of fundamental importance the use of surgical material of good quality and knowledge of the anatomy associated with computed tomography, as well as, whenever possible, prototyping with the main objective of optimizing the results.

\section{Acknowledgments}

The authors are grateful to Edmilson Barbosa da Costa Júnior for their critical review of the manuscript and for support during the development and writing of this manuscript.

\section{Funding}

This study was partially supported by CAPES (Coordenação de Aperfeiçoamento de Pessoal de Nível Superior).

\section{Conflict of interest}

The authors have no proprietary, financial, or other personal interest of any nature or kind in any product, service, and/or company that is presented in this article.

\section{Regulatory Statement}

This study was conducted in accordance with all the provisions of the local human subject's oversight committee guidelines and policies. The patient authorized the disclosure of the case and duly signed the informed consent form.

\section{REFERENCES}

1. Robiony M, Della Pietra L, Bertossi D, Albanese M, Fresku A. A simple method for the repair of frontal sinus fracture: the bone mesh pull-up technique. Craniomaxillofac Trauma Reconstr. 2014 Mar;7(1):79-84. doi: 10.1055/s-0033-1364201. Epub 2014 Jan 9. PMID: 24624261; PMCID: PMC3931769.

2. Schortinghuis J, Zeebregts CJ, Bos RR. Frontal bone reconstruction using patellar bone: a case report. J Oral Maxillofac Surg. 1999 Sep;57(9):1132-3. doi:10.1016/s0278-2391(99)90340-3.

3. Guy WM, Brissett AE. Contemporary management of traumatic fractures of the frontal sinus. Otolaryngol Clin North Am. 2013 0ct;46(5):733-48. doi: 10.1016/.otc.2013.07.005.

4. Gordon CR, Fisher M, Liauw J, Lina I, Puvanesarajah V, Susarla S, et al. Multidisciplinary approach for improved outcomes in secondary cranial reconstruction: introducing the pericranial-onlay cranioplasty technique. Neurosurgery. 2014 Jun;10 Suppl 2(02):179-89; discussion 189-90. doi: 10.1227/NEU.0000000000000296.

5. Montovani JC, Campos LMP, Moraes RS, Ferreira FD, Nogueira EA. Etiology and incidence of facial fractures in adults and children: experience in 513 case. Rev Bras Otorrinolaringol. 2006;72(2):235-41. doi: https://doi. org/10.1590/S0034-72992006000200014

6. Silva JJ, Rocha Neto A, Pereira AM, Correia V, Lira AA. Frontal sinus frontal fracture: clinical case report. Rev Cir Traumatol Bucomaxilofac. 2005;5(3):51-56.

7. Ioannides C, Freihofer HP, Bruaset I. Trauma of the upper third of the face. Management and follow-up. J Maxillofac Surg. 1984 Dec;12(6):255-61. doi: 10.1016/s0301-0503(84)80255-6.

8. Maia M, Klein ES, Monje TV, Pagliosa C. Facial structure reconstruction by biomaterials: literature review. Rev Bras Cir Plast. 2010;25(3):566-72.

9. Maricevich P, Mansur A, Peixoto A, Amando J, Pantoja E, Braune A, et al. Cranioplasties: surgical reconstruction strategies. Rev. Bras. Cir. Plást. 2016;31(1):32-42.

10. Jonkergouw J, van de Vijfeijken SE, NoutE, Theys T, Van de Casteele E, Folkersma $\mathrm{H}$, et al. Outcome in patient-specific PEEK cranioplasty: A two-center cohort study of 40 implants. J Craniomaxillofac Surg. 2016 Sep;44(9):1266-72. doi: 10.1016/j.jcms.2016.07.005.

11. Montovani JC, Nogueira EA, Ferreira FD, Lima Neto AC, Nakajima V. Frontal sinus fracture surgery: epidemiological study and analysis of techniques. Rev Bras Otorrinolaringol. 2006;72:204-209.

12. Reardon EJ. Navigational risks associated with sinus surgery and the clinical effects of implementing a navigational system for sinus surgery. Laryngoscope. 2002 Jul;112(7 Pt2 Suppl 99):1-19. doi: 10.1002/ lary.5541121301.

Emerson Filipe de Carvalho Nogueira (Corresponding address)

Department of Oral and Maxillofacial Surgery. University of Pernambuco. Recife, Pernambuco, Brazil.

Email: emerson_filipe@hotmail.com

Date submitted: 2020 0ct 26 Accept submission: $2021 \mathrm{Jul} 23$ 